\title{
ODGOJNO-OBRAZOVNA MISAO HUSEINA ĐOZE I FETHULLAHA GULENA
}

\section{Sažetak}

U ovom naučnom radu se, na osnovu analize odgojno-obrazovne misli Fethullaha Gulena i Huseina Đoze, nastoje utvrditi eventualne korelacijske veze između ǔ́enja ovih dvaju učenjaka. Početna teza jeste da njïhova odgojno-obrazovna misao sadrỹi veliki broj zajedničkih elemenata. Buduci da o slicnoj temi do sada nije pisano, značaj za pedagošku nauku, posebice onu s islamskim prefiksom, je veliki. Rad je sastavljen od više poglavlja, u kojima se obraduju rajednički aspekti odgojne misli Gulena $i$ Đoze, od kojih su neka: pojam $i$ značaj obrazovanja, drustveni aktivizam $i$ bitnost objedinjenja teorije $i$ prakse, odnos izmedu religijskog i svjetovnog znanja, licnosti odgajatelja i odgajanika, te odgojni proces. Metode rada koje su koristene: analitička metoda (analiza sadr:̌aja, funkcionalna analiza, komparativna analiza), deduktivna metoda, sinteza $i$ metoda apstrakcije. Rad je došao do rakljuckea da su Gulen $i$ Đozo nastojali da u islamske studije ponovno uvedu ili reafirmiraju dinamično razumijevanje kur'anske ideje vremena $i$ historije, na način na koji su to $i$ najveci klasični autoriteti cinili, stvarajuci brilijantnu intelektualnu tradiciju sa kojom se muslimani uvrštavaju $u$ red najciviliziranijih naroda $u$ dosadašnjoj povijesti covječanstva. Time je poturdena početna bipoteza rada o mnogobrojnim korelacijskim vezama između misli i djela ova dva islamska ǘenjaka, a kao doprinos islamskoj pedagoškoj misli.

Ključne riječi: Gulen, Đozo, odgojno-obrazovna misao, korelacija, islamska pedagogija

\section{Uvod}

Sva hvala i zahvala pripada samo Allahu ,dž. š., neka je salavat i selam na Njegovog posljednjeg Poslanika i miljenika, pečata svih vjerovjesnika, na njegovu časnu porodicu, uzorite ashabe i sve one koji ga slijede do Sudnjeg dana, amin!

Tema ovog naučnog rada je vezana za odgojno-obrazovnu dimenziju rada i djela Huseina-ef. Đoze i Fethullaha Gulena, i njenu povezanost s univerzalnim islamskim učenjem. Islamska pedagogija, koja je na području $\mathrm{BiH}$ nažalost nedovoljno poznata, svakako nudi rješenja za probleme koji muče podjednako omladinu, ali i sve one koji su na 
neki način vezani za odgojni proces. Treba istaći da islam svoje sljedbenike podučava i odgaja na najljepši i najplemenitiji način, te da predstavlja idealan program življenja objavljen od Uzvišenog Allaha radi dobrobiti čitavog čovječanstva.

Cilj ovog istraživanja jeste komparativna analiza odgojnoobrazovne misli Fethullaha Gulena i Huseina-ef. Đoze.

Zadaci su slijedeći:

- analizom njihovih djela, utvrditi odnos Huseina Đoze i Fethullaha Gulena spram pojmova obrazovanja i odgoja, uključujući definiciju, značaj, te izvore odgojne misli,

- utvrditi postojanje zajedničkih tačaka,

- objediniti u cjelinu njihovu odgojno-obrazovnu misao kao paradigmu islamske pedagoške misli.

Početna hipoteza jeste da njihov rad i djelo imaju velikih korelacijskih poveznica, što može imati veliki značaj za daljnji razvoj pedagoške nauke na našim prostorima, pa i šire. Metode rada koje su korištene: analitička metoda (analiza sadržaja, funkcionalna analiza, komparativna analiza), deduktivna metoda, sinteza i metoda apstrakcije.

Početni dio rada posvećen je kratkom osvrtu na život i djelo Fethullaha Gulena i Huseina Đoze. Potom je kroz više poglavlja obrađena njihova odgojno-obrazovna misao, i to slijedećim nizom:

- Pojam i svrha obrazovanja;

- Ukazivanje na posljedice zanemarivanja odgoja i obrazovanja;

- Odnos spram religijskog znanja i svjetovnih nauka;

- Sinteza tradicionalnih i savremenih ideja;

- Društveni aktivizam i objedinjenje teorije i prakse kao prioriteti odgojno-obrazovne misli;

- Uloga i kompetencije odgajatelja;

- Ličnost odgajanika i odgojni proces.

Motiva za pisanje o ovoj temi ima napretek. Pisati o takvim velikanima islamske misli poput Fethullaha Gulena i rahmetli Huseina-ef. Đoze, o ljudima koji iza sebe imaju ogromna djela, ogroman rad za islam, 
i naravno ogroman uspjeh koji su ostvarili na polju islamske odgojnoobrazovne misli, je velika čast za bilo kojeg muslimana, pa tako i za autore ovog članka. Đozo i Gulen pripadaju grupi učenjaka koji su dali nemjerljiv doprinos u razvoju i razumijevanju misije islama, kao i savremene islamske misli. Većina tema kojima su se oni bavili u svojoj vjerskoj i svjetovnoj misiji su aktuelne prirode sa jasnom i vidljivom intencijom progresa i napretka muslimana, koji su bili izloženi taklidu (slijepom oponašanju) koji je svakako bio i ostao najveći uzrok pada, dekadence i zaostalosti muslimana.

Kao glavna literatura za rad su poslužila objavljena Sabrana djela Huseina Đoze, te na bosanski jezik prevedena djela Fethullaha Gulena. Ipak, veliki dio vremena bio je utrošen na iščitavanje literature na engleskom jeziku na kojem su zapisani brojni Gulenovi radovi i članci.

Prilikom odabira teme i njenog pisanja vođeno je računa o originalnosti $\mathrm{i}$ autentičnosti te se može odgovorno reći da o navedenoj temi do sada nije urađen niti jedan sličan rad, bilo na bosanskom, niti na drugim jezicima. Dakle, postoji mnogo prostora za daljnji doprinos izučavanju date problematike, te se nadamo da će ovaj rad biti početni iskorak na tom putu.

$\mathrm{Na}$ kraju, nadamo se da smo sa ovim svojim skromnim radom uspjeli da bacimo barem malo svjetla na odgojno-obrazovnu misao Husein-ef. Đoze i Fethulaha Gullena, njihov na rad i trud u pokušajima i nastojanjima da osvijeste i podstaknu ljude na učenje i stjecanje šerijatskog i svjetovnog znanja, i borbu protiv pasivnosti i inertnosti.

\section{Kratki osvrt na život i djelo Fethullaha Gulena i Huseina Đoze}

\subsection{Husein-ef. Đozo}

Rahmetli hadži Husein-efendija Đozo, dugogodišnji profesor u Gazi Husrev-begovoj medresi i na Islamskom teološkom fakultetu u Sarajevu i predsjednik Izvršnog odbora Udruženja „Ilmije“ u Bosni i Hercegovini, je rođen 3. jula 1912. godine u selu Bare, nedaleko od Goražda, a na ahiret je preselio 30. 5.1982. godine u Sarajevu, na funkciji savjetnika Reis-ul-leme i vjersko-prosvjetnog refrenta VIS-a.

Husein-efendija Đozo je pohađao nekoliko medresa. Prvu u Foči. Nakon završetka medrese u Foči, Husein-efendija Đozo je nastavio 
školovanje u Sarajevu u Merhemića medresi. Iz tih dana sjećao se: Haď̌ $i$ Hasan-ef. Muhamedagic - Bišcak bio mi je muderris u Merhemica medresi u Sarajevu. Bio je wijeke u opoziciji $i$ nezadovoljan stanjem u Islamskoj zajednici. ${ }^{1}$ Možda se zbog njega Husein-efendija Đozo trajno opredijelio za poziciju.

Iz Merhemića medrese Husein-ef. Đozo prelazi u Gazi Husrevbegovu medresu, pa u Šerijatsku sudačku školu i, po njenom završetku, kao stipendist Vakufske direkcije, odlazi na studije u Egipat na univerzitet sa milenijskom tradicijom - El-Azhar gdje završava Šerijatsko-pravni fakultet 1937/38. godine. Iako tada El-Azhar nije bio potpuno reformiran, nekoliko predavača ostavilo je dubok utisak na Husein-efendiju $\mathrm{i}$ on je to s ponosom isticao: Smatram veoma sretnom

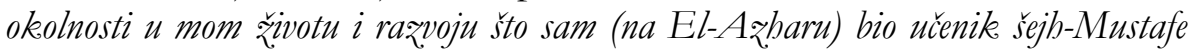

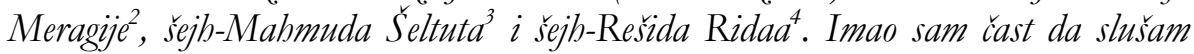
njihova predavanja $i$ da s njima osobno kontaktiram. ${ }^{5}$ Poslije završenih studija, Husein-efendija Đozo se vraća u domovinu i uključuje u vjerskoprosvjetni rad u Islamskoj zajednici.

\footnotetext{
1 Ibid., str. 148.

2 Ahmed b. Mustafa El-Meragi (nepoznat datum rođenja-1952.), je bio egipatski učenjak i mufessir, diplomirao je na fakultetu Daru-l-ulum, a nakon toga je na istoj ustanovi predavao šerijatske znanosti. Poslije je imenovan profesorom arapskog jezika i šerijatskih znanosti na fakultetu Gordon u Kartumu, a umro je u Kairu. Od njegovih djela ističemo: El-Hisbe fi-l-islam, El-Vedžiz fi usuli-l-fikh, Tefsiru-l-Meragi itd. Preuzeto iz: Abdulkadir Muhammed Salih, Tefsir i mufessiri u savremenom dobu, FIN i ElKalem, Sarajevo, 2008., str. 461.

${ }^{3}$ Mahmud Seltut (1893-1963.), proslavljeni rektor Univerziteta El-Azhar u Kairu, je bio jedan od najvećih islamskih učenjaka prošlog stoljeća. Izvor: Šeltut Mahmud, Komentar Kur'an-i-kerima (prvih deset ď̌uzeva), FIN i El-Kalem, Sarajevo, 2008., str. 5.

${ }^{4}$ Muhammed Rešid Rida (1865-1935.) bio je jedan od najistaknutijih učenjaka u prvoj polovini XX stoljeća. Jedno vrijeme je bio pod utjecajem tesavvufa, da bi, zatim, susrećući se sa idejama Afganija i Abduhua, postao jedan od nosilaca reformizma u islamskom svijetu i Abduhuov nasljednik u savremenoj racionalističkoj školi tefsira. Dugo godina je bio Abduhuov prvi saradnik, te pokretač i urednik časopisa El-Menar, koji je imao jakog odjeka širom islamskog svijeta. Nakon Abduhuove smrti, po njegovom metodu, nastavio je sa tumačenjem tefsira, tako da se smatra koautorom tefsira Tefsiru-l-Kur'ani-l-hakim, skupa sa Muhammedom Abduhuom. Preuzeto iz: Adilović Ahmed, Velikani tefsirskih znanosti, Elči Ibrahim-pašina medresa u Travniku, Travnik, 2003., str. 277.

${ }^{5}$ Bušatlić Ismet, Život $i$ djelo rada $i$ ibreta, objavljeno u: Zbornike radova, Fakultet islamskih nauka u Sarajevu, br. XI., strana 148.
} 
Rahmetli hadži Husein-efendija Đozo, dugogodišnji profesor u Gazi Husrev-begovoj medresi i na Islamskom teološkom fakultetu u Sarajevu i predsjednik Izvršnog odbora Udruženja „Ilmije“ u Bosni i Hercegovini, na ahiret je preselio 30. 5. 1982. godine u Sarajevu, na funkciji savjetnika Reis-ul-leme i vjersko-prosvjetnog refrenta VIS-a.

\subsection{Fethullah Gulen}

Fethullah Gulen (rođen 27. aprila 1941.) je turski pisac, pedagog i islamski učenjak. On je osnivač Hizmet pokreta. Trenutno živi u egzilu u Pensilvaniji, u Sjedinjenim Američkim Državama. ${ }^{6}$

Aktivno je uključen u društvenu debatu vezanu za pitanja budućnosti Turske, kao i ulogu islama u modernom svijetu. U medijima na engleskom jeziku se opisuje kao jedna od najvažnijih islamskih ličnosti u svijetu.

Autor je preko 60 knjiga i mnogobrojnih članaka koji pokrivaju niz oblasti: društvene, političke i religijske teme, umjetnost, nauka i sport i snimio je hiljade sati audio i videomaterijala. Na bosanski jezik je prevedeno više njegovih knjiga, od kojih po značaju izdvajamo djela Beskrajna svjetlost - Muhammed, a.s., (2 toma), kao i Svjetlosti na putu Istine, koja su i poslužila kao literatura za ovaj članak.

\section{Pojam i svrha obrazovanja u misli Huseina Đoze i Fethullaha Gulena}

Oni koji žele da predvide budućnost jednog naroda mogu to da učine analizom njegovog obrazovnog sistema i metoda kojima se odgajaju mlade generacije. ${ }^{7}$ Fethullah Gulen

Obrazovanje je najbitnija kvaliteta koji dijeli čovjeka od drugih živih bića. U ovom radu ćemo, budući da govorimo o terminima odgoja i obrazovanja prvenstveno u islamskoj pedagoškoj misli, na početku navesti termine koji u arapskoj lingvističkoj nauci tretiraju pojam obrazovanja.

Arapski jezik ima tri termina za obrazovanje, koji predstavljaju različite dimenzije odgojno-obrazovnog procesa u islamskoj koncepciji

\footnotetext{
${ }^{6}$ http://en.wikipedia.org/wiki/Fethullah_G\%C3\%BClen

7 http://www.fethullahgulen.org/about-fethullah-gulen/as-a-teacher/819-youth.html
} 
života. Najčešće upotrebljavana riječ za obrazovanje u formalnom smislu je ta'lim, iz korijena 'alime (znati, biti svjestan, vidjeti, kako bi naučili), koji se koristi za označavanje znanja koje se traži ili prenosi preko nastave i nastavnog procesa. Terbije, od korijena reba (povećati, rasti, straga), podrazumijeva stanje duhovne i etičke njege u skladu s Božjom voljom. Te'dïb, od korijena aduba (biti kulturan, prefinjen, dobro vaspitan), sugerira razvoj osobe $\mathrm{s}$ lijepim društvenim ponašanjem u skladu s islamskim bontonom. Obrazovanje se u kontekstu islama posmatra kao proces koji uključuje cjelovitu osobu, uključujući i racionalne, duhovne i društvene dimenzije čovjeka.

Prema Syed Muhammad Naquib Al-Attasu, pojam te'dib, ako se pravilno razumije i tumači, predstavlja tačan pojam za islamsko obrazovanje, a ne pojmovi ta'lim i terbijeh. Naime, on odbacuje pojam terbije zato što se on odnosi samo na fizički aspekt u slučaju biljaka i jedino na fizički i emocionalni aspekt u slučaju životinja i čovjeka. Śto se tiče pojma ta'lim, on se općenito ograničava na kognitivne aspekte obrazovanja. Cilj islamskog obrazovanja je formiranje odgojenog čovjeka koji je iskreno svjestan svoje odgovornosti prema jedinom Bogu; ko razumije $i$ ispunjava svoje obaveze prema sebi $i$ drugima u drustvu na pravičan način; ko neprestano tę̌i usavršavanju svakog aspekta sebe prema savršenom covjeku adaba. ${ }^{8}$

Prethodno citirana definicija čovjeka kakvog formira islam izuzetno lijepo opisuje i djelo i misao Huseina Đoze i Fethullaha Gulena. Zanimljivo je da su oni, u različitim socio-ekonomskim i religijskim uslovima, radili na postizanju identičnog cilja: kvalitetan odgoj budućih generacija je ključni faktor uspjeha čitavog naroda.

Gulen i Đozo su podučavali da je učenje obaveza cijelog ljudskog roda $\mathrm{i}$ da kroz stjecanje znanja postižemo stepene istinskih ljudi i postajemo koristan dio društvene zajednice. Nemarnim odnosom spram odgoja djece, dovodimo u opasnost ne samo sadašnjost, već i budućnost jednog naroda: Druśtvena struktura jednog naroda je blisko vezana s važnošćn koju taj narod pridaje obrazovanju. Obrazovanje trenutne generacije je posebno bitno buduci da će oni postati odgajatelji budućib generacija i oni će sa svojim učenicima da dijele znanje koje su stekli kroz svoje obrazovanje i iskustvo. Ključno je za jedno

\footnotetext{
8 Wan Mohd Nor Wan Daud, Syed Mubammad Naquib Al-Attas - obrazovna filozofija i praksa, Tugra, Sarajevo, 2010., str. 163.
} 
drustvo i moral tog drustva da se njegove vrijednosti prenesu na mlade generacije u procesu edukacije.

Čovjek se potvrđuje kroz humanizam i ostvarivanje duhovnih moralno-etičkih vrijednosti. S tim u vezi Husein-ef. Đozo kaže: $U$ čovjeku djeluju dvije dispozicije, jedna je razum kao izvor spoznaje, a druga je srce kao iqvor vrline. Razum saznaje $i$ otkriva, a vrlina pokré́e na akciju. Nanka covjeka năi $i$ obrazuje, vjera ga uči i odgaja. Nauka i vjera se uzajamno dopunjuju. Nanka bez vjere i morala vodi sili i nasilju, vjera $i$ moral bez nanke vodi u mistiku, metafiziku $i$ izolaciju. Ni nauka ni vjera ne smiju biti zloupotrijebljene. ${ }^{10}$

Prema Gulenu i Đozi, u islamskim obrazovnim teorijama znanje se stječe kako bi se aktualizirale i usavršile sve dimenzije ljudskog bića. Iz islamske perspektive najviši i najkorisniji model savršenstva je ličnost Muhammeda, s.a.v.s., a cilj islamskog odgoja je da ljudi mogu živjeti kao što je on živio. Kao što je navedeno od strane El-Attasa, sveobuhvatan i integriran pristup obrazovanju u islamu je usmjeren prema uravnotę̌enom rastu ukupne osobnosti (...) kroz obuku ćovjekovog duba, intelekta, racionalnog bića, osjećaja i tjelesnih osjetila (...) tako da je vjera utkana u cjelinu osobnosti. ${ }^{11}$

U svojim djelima Gulen i Đozo pažnju nisu posvećivali samo odgoju djece, već odgoju svih ljudi. Ideal cjeloživotnog učenja je nešto na čemu su insistirali, kao $i$ težnja za popravljanjem samib sebe. ${ }^{2}$ Prema njima, obrazovanje s jasnim ciljem ima pozitivne efekte ne samo na pojedince, već i na globalnu zajednicu. To podrazumijeva $i \mathrm{da}$ anarhija u obrazovnom sistemu pogubno djeluje na cjelokupan edukacijski proces: Obrazovni sistem bez jasno definisanog cilja $i$ surbe će samo zbuniti nadolazéce generacije. Mi moramo obratiti pa:̌nju da naša omladina usvaja żnanja na efektan način kako bi se osiguralo da istinski ǔ́e, a ne samo sakupljaju informacije.

Njihov pristup obrazovanju svoje uporište ima u toleranciji i strpljenju, a ne u potiskivanju tuđeg i drugačijeg. Odgoj i služenje ljudima doprinosi eliminaciji društvenih problema, devijacija i do uspostave boljih međuljudskih, pa čak i međudržavnih odnosa. Popravak zajednice se može postići podizanjem budućih generacija na nivoe istinskih

9 Ünal, Ali and Alphonse Williams, eds., Advocate of Dialogue: Fethullah Gülen. Fairfax, VA: The Fountain, str. 308.

10 Wan Mohd Nor Wan Daud, Syed Mubammad Naquib Al-Attas - obrazovna filozofija $i$ praksa, str. 154.

11 Ibid., str. 161.

12 Ünal, Ali and Alphonse Williams, eds. Advocate of Dialogue: Fethullah Gülen, str. 306. 
humanista, a ne izopćavanjem loših, a na tom planu odgoj i obrazovanje igraju presudnu ulogu, kako to ističe Gulen: Ljudska bica su najčasnija od svih bića. Svako ko želi da uvé́a svoju vrijednost trebao bi da sluři ovim časnim bicima. Sto se tič medunarodnih odnosa i covječanstva, jedan od najvažnijih faktora je da eliminišemo stvari koje razdvajaju ljude, poput egoizma, sopstvenih interesa $i$ diskriminacije, bez. obzira da li na osnovu boje kože, rase, vjerovanja ili etničke pripadnosti. Ove stvari dovode do konflikta kada se idealizuju i mogu biti iskoristene od velikih sila. Ova zla može iskorijeniti pomoćn odgoja i obrazovanja. Takoder, edukacija je najefektniji $i$ najuobičajeniji vid sporazumijevanja s drugima. ${ }^{13}$

\subsection{Pogubne posljedice nemarnog odnosa spram odgoja i obrazovanja}

Đozo i Gulen su isticali i probleme koji nastaju ukoliko narod zanemari stjecanje nauke. Odmakom od učenja svoje čiste vjere, muslimani su nazadovali u svakom pogledu. Povratkom izvorima vjere i obrazovanju koje je bazirano na univerzalnim principima islamskog učenja muslimani imaju priliku da svijetla obraza zakorače u budućnost. No, ne bi smjeli upasti u zamku kopiranja tuđeg i svačijeg jer bi s time narušili tekovine sopstvene kulturne i vjerske prošlosti: Obrąovanje zauzima veoma istaknuto mjesto u životu svakog naroda. Svako obrazovanje koje je prožeto prošlošcu naroda i povezano s korijenima njegovog duha može osvijetliti ispred njega put rivota $i$ napredak. U suprotnom, kada se narod predaje u krila strane misli $i$ obrazovanja $i$ ide kolebajuci se čas desno, čas lijevo, to ce dovesti do njegovog raspadanja $i$ išcernnuća. ${ }^{14}$

Dakle, odgojna misao Đoze i Gulena ukazuje na važnost inovacija i originalnosti. Islam nas uči da budemo originalni, posebni, jedinstveni. Puko kopiranje tuđeg obrazovnog sistema može dovesti do otuđenja odgajanika od vlastite kulture i religije, a ima li većeg gubitka? U tom smislu rahmetli Đozo je ukazivao na odvajanje Bošnjaka od učenja, knjige i nauke. Tako on navodi da je jednom prilikom navratio kod prijatelja koji ima luksuznu kuću, skupocjen namještaj i razne suvenire, ali nigdje niti jedne knjige. Husein-ef. pita domaćina ima li biblioteku ili bar nekoliko knjiga, a ovaj mu odgovara: Neka biblioteke osnivaju $i$ knjige kupuju ǔ́eni ljudi. Meni je va:̌no da obezbijedim djeci uvjete za udoban $i$ bez̧brižan

\footnotetext{
${ }^{13}$ http:/ /www.fethullahgulen.org/about-fethullah-gulen/education/778-educationalservices-spreading-throughout-the-world.html

${ }^{14}$ Gulen Fethullah, Svjetlosti na putu Istine, El-Kalem, Sarajevo, 2011., str. 91.
} 
život. ${ }^{15}$ Ovim susretom i odgovorom Husein-ef. Đozo je razočaran i navodi primjer iz vremena kada su živjeli age i begovi. Oni su imali velika imanja, a njihovi sinovi, izuzev pojedinaca, nisu pohađali škole. Mislilo se da je imetak najveća snaga, sigurnost i zaštita. Kada je provedena agrarna reforma $\mathrm{i}$ imetak oduzet agama i begovima, njihovi neobrazovani sinovi postali su sirotinja i sluge drugima.

Druženje s prijateljem Đozo završava riječima: Knjige su najljepšsi ukras stana, one su najveía vrijednost. Nauka, znanje i prosvjeta su najsigurnije bogatstvo jednog naroda $i$ najmoćnije orušje $u$ zaštiti slobode $i$ dostojanstva $i$ pojedinaca i naroda. ${ }^{16}$

Husein-ef. Đozo se pita: Zašto su muslimani uspostavili razliku izmedu "kitaba" i knjige? U svijesti mnogih muslimana kult kitaba nije prenesen na savremenu knjigu. Došlo je do određene konfrontacije i podjele nauke na vjersku i svjetovnu. Što bi značilo, vjerske nauke su u kitabima, a svjetovne u knjigama. Tu su začeci propadanja kulta knjige u očima muslimanskih masa. Bilo je prilično kobno što nova savremena knjiga nije odmah prihvaćena kao kitab, kao izvor naučnih saznanja i potreba. Izostala je svijest koja je na kraju dovela do slabosti čitavog naroda.

\subsection{Odnos spram religijskog znanja i svjetovnih nauka u misli Fethullaha Gulena i Huseina Đoze}

Obrazovanje u islamu je dvojako: stjecanje intelektualnog znanja (kroz primjenu razuma i logike) i razvoj duhovnog znanja (izvedeno iz božanske Objave i duhovnog iskustva). Prema svjetonazoru islama, u obrazovanju moraju biti podjednako zastupljene obje komponente. Stjecanje znanja u islamu nije samo po sebi cilj, već služi kao sredstvo za poticanje više moralne i duhovne svijesti, što dovodi do vjere i dobrih djela. Isključivo obrazovanje samo intelektualnih kapaciteta, na primjer, je neadekvatno u razvoju osjećaja ljubavi, dobrote, suosjećanja i nesebičnosti, koji su duhovni ambijent i mogu biti angažirane samo kroz duhovni trening.

Jedan od izazova koji se postavljaju pred islamskom pedagogijom jeste i odnos između islama s jedne strane i modernosti i nauke s druge strane. Gulen smatra da je ovaj odnos nekoć bio problematičan, posebno

\footnotetext{
15 Latić Džemaludin, Husein-ef. Đozo kao islamski modernist, objavljeno u: Život $i$ djelo Husein-ef. Đoze - Zbornik radova sa naučnog simpozija, str. 143.

${ }^{16}$ Ibid., str. 145.
} 
u oblasti prirodnih nauka, ali ističe da je taj navodni razdor pogrešno shvaćen i da ne postoji oprečnost između islama i znanja. Kao odgovor skepticima, Gulen skreće pažnju na mišljenje jednog od najvećih naučnika XX vijeka: Einstein je rekao da nas nauka podučava odnosu ižmedu fenomena $i$ kako odredene pojave skupa egzistiraju unutar specificnih uvjeta. On je naveo i da nas nauka, sastavljena od znanja o onome sto postoji, ne podućava onome kako bi trebalo biti; samo nas religija podućava tome kako bi stvari trebalo da iəgledaju $i$ kojim bismo ciljevima trebali tę̌iti. ${ }^{17}$

Naučna i tehnička dostignuća izazvala su duboke promjene u životu, shvaćanjima i odnosima ljudi. Čovjek je ponesen ovim progresom. On ga je usvojio i okupirao svu njegovu pažnju. Stavlja pred njega nove potrebe $\mathrm{i}$ nove dileme. Materijalni interes je osnovna preokupacija savremenog čovjeka. Pokretač je svih akcija i osnovni cilj svih ljudskih nastojanja. Duhovne vrijednosti, kao važna komponenta ljudskog postojanja, potiskuju se u drugi plan. Zato i vjeru treba tumačiti $\mathrm{u}$ duhu vremena, jer joj samo tako možemo obezbijediti mjesto u savremenom društvu. Covjek je ovladao prirodom i dijelom kosmosa, ali nije ovladao svojom vlastitom prirodom. Mnoge anomalije, poroci, sila i nasilje u svijetu, posljedica su poremećaja ravnoteže između duhovnih i materijalnih vrijednosti; to je disharmonija između obrazovanja i odgoja, razuma i srca, teorije i prakse, znanja i ponašanja.

Ukoliko umovi novih generacija budu opskrbljeni s naukama svoga vremena, a njihova srca pritom ostanu neokrnjena i ukoliko im se pruži kvalitetno obrazovanje, ukoliko im se obezbijede uslovi za normalno učenje i prilike za napredovanje, oni se mogu nadati svijetloj budućnosti. Ove generacije će imati sposobnost da se suoče sa svakom preprekom na životnom putu; oni će biti u stanju da - dubovno i materijalno - prevaridu svaki vid teškoće i nikad néce padati u očaj. Tada će se isplatiti sve žrtve koje smo podnijeli kako bismo prǔ̌ili našoj djeci bolje obrazovanje. A sto se tiče onih nesretnih, koji su lišeni ove svijesti, oni ce upropastiti naslijede svojih očeva; $s$ dubovne strane, oni će voditi nestabilan i pesimističan æ̌ivot, i na koncu će skončati u poniženju. ${ }^{18}$

17 Ünal, Ali and Alphonse Williams, eds. Advocate of Dialogue: Fethullah Gülen, str. 45.

18 Prljača Mustafa, Husein Đozo sabrana djela, knjiga prva, tom I, El-Kalem, Sarajevo, str. 718. 


\subsection{Sinteza tradicionalnih i savremenih ideja u misli Fethullaha Gulena i Huseina Đoze}

Odgojno-obrazovna misao Huseina-ef. Đoze i Fethullaha Gulena počiva na premisi da čovjek u životu ne smije biti samo pasivni posmatrač. Źivot možemo mijenjati tek onda ako se uključimo u njegove tokove i postanemo aktivni faktori u njemu.

Društvena korist jednog čovjeka, njegova angažiranost, aktivnost, i usmjerenost u pravcu dobrobiti čovjeka i društva, čini osnovni element u sadržini islamskih propisa i principa. Samo vjerovanje u Boga nema nikakvog drugog cilja, nego da aktivizira čovjeka u borbi za dobro, da formira u njemu zdravu, konstruktivnu i društveno korisnu ličnost, da ga otvori i okrene prema drugima i da ga oslobodi pritiska strasti i ličnih, sebičnih interesa. Takav smisao imaju svi islamski obredi: namaz, post, zekat, Hadž itd.

Da bismo realizirali jasne kur'anske imperative, nužno je da objedinimo vrijednosti iz prošlosti s dostignućima iz sadašnjosti. Nove generacije imaju svoje potrebe i probleme, imaju svoj jezik i razumijevanje povijesti. Islamski učenjaci iz prošlosti, umjesto susreta sa novim idejama i nuđenja rješenja, bilo iz straha, opreza ili neznanja, povlačili su se i zatvarali. Umjesto susreta sa savremenim idejama, pa ako treba i konfrontacije s njima, ulema se izolirala misleći da će na taj način sačuvati izvornost islamskog učenja: Dok god ne potpomognemo našu omladinu putem obrazovanja, oni će biti zarobljenici okrǔ̌enja. Oni lutaju bez ikakvog cilja, nošeni jedino strastima $i$ daleko od nauke $i$ razuma. Oni mogu postati istinski predstavnici nacionalne misli $i$ osjećaja ukoliko ib njibovo obrazovanje poveže s njihovom prošlošcu i mudro ih pripremi za njihovu budućnost. ${ }^{19}$

Sinteza novih i starih ideja je težak i složen zadatak. Zato Gulen i Đozo kao izlaz vide sintezu tradicionalnog i savremenog, a prepreka za to je prihvatanje forme kao trajnog i nepromjenljivog principa. Često se događalo da se modifikacija uzima umjesto principa, odnosno forma umjesto suštine. U tom slučaju, forma dobiva trajnu vrijednost i pretvara se u neprebrodivu smetnju na putu daljeg kretanja.

Da bi se ta smetnja otklonila, treba demistificirati prošlost. Prošlost je osnova za dalje kretanje. U njoj se otkriva ono što je trajno i što može i dalje živjeti. Ne možemo živjeti u prošlosti, ali ne možemo ni s njom

${ }^{19}$ http://www.fethullahgulen.org/about-fethullah-gulen/as-a-teacher/819-youth.html 
prekinuti veze. Svaka generacija mora ići dalje i pronalaziti recepte za aktualne probleme. Samo oni koji u historiji daju svoj doprinos i pomognu da se ide dalje, oni su interesantni za bistoriju i njihova imena se bilję̌ę. ${ }^{20}$

Rješenje uspješne sinteze prošlosti i sadašnjosti, prema Đozi i Gulenu, leži u braku i zasnivanju porodice. Prije svega, treba napomenuti da je porodica osnovna ćelija svake zajednice, svakog naroda i svake države. Svaka akcija i svaka korisna misija, koja ima za cilj opće dobro, treba da počne tu, u porodici. Prema tome, svako nastojanje u vezi s brigom oko materijalnog zbrinjavanja porodice i oko njenog duhovnog odgoja spada u okvir vršenja dužnosti odgoja i obrazovanja.

Roditelji kao odgovorni članovi porodice ne smiju nijednog trenutka smetnuti s uma da je sudbina njihove djece u njihovim rukama. Vršeći roditeljsku dužnost kako treba, oni time izvršavaju na najbolji način i svoju dužnost potpomaganja čitavog naroda: Iquzetno je bitno za društvo u cjelini $i$ za njegov moral da se njegove vrijednosti (duhovne, moralne) prenesu na mlade generacije u obrazovnom procesu. Prijenos vrijednosti s jedne na drugu generaciju se najefektnije prenosi vrši preko uspješne brä̌ne zajednice, što čini porodicu vå̌nom obrąovnom institucijom; štaviše, ključnom za kontinuirano postojanje cijele zajednice. Oni narodi koji ne uspiju da formiraju instituciju braka na zdravim $i$ jakim osnovama su osudene na iqumiranje. ${ }^{21}$

\subsection{Društveni aktivizam i objedinjenje teorije i prakse kao prioritet odgojno-obrazovne misli}

Ovaj segment odgojne-obrazovne misli Huseina Đoze i Fethullaha Gullena odnosi se na vezu islamskog obrazovanja s razvojem svijesti kod odgajanika i odgajatelja o društvenom aktivizmu kao simbolu časnih i odgojenih ljudi. Riječi i djela čovjeka kojeg je islam odgojio idu ruku pod ruku, jer musliman mora stalno biti angažovan u borbi na polju pobjede dobra, istine i pravde, kao i na polju suzbijanja zla, zabluda i nasilja. On svoja vjerovanja, svoju pripadnost islamu, odanost i vjernost Bogu i Božijem Poslaniku dokazuje i potvrđuje samo i isključivo kroz svakodnevnu aktivnost, ponašanje i odnos prema drugima.

\footnotetext{
20 Wan Mohd Nor Wan Daud, Syed Muhammad Naquib Al-Attas - obrazovna filozofija $i$ praksa, str. 157.

21 http://www.fethullahgulen.org/about-fethullah-gulen/education/777-educationfrom-cradle-to-grave.html
} 
Principi, učenja i sistemi bez primjene i realizacije u svakidašnjem životu ostaju puke fraze i apstrakcije bez ikakve koristi. Nauka bez praktične primjene je, kako stara mudrost kaže, kao voćka bez ploda. Zato je Muhammed, a.s., često, obraćajući se Bogu, molio da ga zaštiti od nauke koja ne daje korisnih rezultata. Kur'an na više mjesta osuđuje raskorak između riječi i djela: $\boldsymbol{O}$ vjernici, zašto jedno govorite, a drugo radite? O, kako je Allahu mrsko kada govorite riječi koje djela ne prate. ${ }^{22}$

Islam obavezuje svakog muslimana da u granicama svojih mogućnosti i odgovornosti aktivizira i podstiče i druge. U tom pogledu je vanredno značajna ustanova upućivanja na dobro i sprječavanja zla. Nije dovoljno, prema ovom principu, što će čovjek osobno činiti dobro i ustezati se od zla. On mora $i$ druge nagoniti i podsticati na dobro, odnosno sprječavati od zla ili, u najmanju ruku, osuđivati i mrziti njihovu štetnu djelatnost. U tome se polazi od činjenice da pojedinačne djelatnosti, ako ne čine sastavni dio opće zajedničke aktivnosti, ne znače mnogo. Tek kada se slivaju u zajednička nastojanja i na taj način tvore jedinstvo akcije i jedinstvo misli, tada postaju u stanju da prebrode sve poteškoće i da se suoče sa svin preprekama. Time se stvara javno mijenje koje vrši snažan pritisak na društvene izgrednike i predstavlja veoma značajan usmjeravajući faktor. ${ }^{23}$

Kur'an i sunnet posvećuju veliku brigu ovoj ustanovi i pridaju vanredan značaj njenoj funkciji. Ustanova upućivanja na dobro i sprječavanja zla predstavlja naročitu vrstu društvene kontrole, ali kontrole koja se ne obavlja samo putem posebnih komisija, organa i zakona. Osnovni element u ovoj kontroli jeste svijest i savjest pojedinaca, koje se pretvaraju u zajedničku društvenu svijest i savjest, a potom formiraju javno mijenje koje vrši svoj utjecaj.

Prema islamskom učenju svaki musliman je obavezan da vrši društvenu kontrolu, da opominje, ispravlja, savjetuje i upućuje drugog. Danas, u procesu buđenja i oživljavanja pravih islamskih vrijednosti, postavlja se u vrlo oštroj formi pitanje punog okretanja životu. Nova preorijentacija, koja počiva na oživljavanju prave dinamične islamske misli, polazi od islamskog principa da se samo kroz korisnu životnu aktivnost, kroz djela koja koriste drugima, postiže sevab, nagrada na

\footnotetext{
${ }^{22}$ Kur'an, Es-Saff, 3.

23 Prljača Mustafa, Husein Đozo sabrana djela, tom I, 423-424.
} 
onome svijetu. Koliko u ovom zemaljskom životu doprinesemo u borbi protiv nepravde, neznanja, opće zaostalosti, nasilja, nejednakosti itd., toliko ćemo dobiti na drugom svijetu, ahiretu. Nema sré́e na abiretu bez. sréce na dunjaluku i obratno. Sré́a na abiretu zaraduje se, prema islamskom ǘenju, putem brige o drugom. Koliko za drugog, za drustvo žrtvujemo i učinimo, toliko ćemo dobra naći i na abiretu. Koliko zla suəbijemo na dunjaluku, toliko ćemo dobra naći na abiretu. ${ }^{24}$

Kad čitamo riječi Đoze i Gullena o stanju ljudi, dolazimo do zaključka kako i mi živimo u vremenu u kojem se pred muslimane postavlja imperativ zajedničkog rada radi dobrobiti cijelog društva, ne obazirući se na sitne lične interese. Nama nedostaje istinskog vjerskog obrazovanja i tu dolazi do izražaja uloga odgajatelja (imama, hatiba, muallima, profesora u obrazovnim institucijama) da se preko vjeronauke u školi, u mektebima i na hutbama osvijeste muslimani i okrenu ka nauci, učenju i izučavanju i vjerskih i društvenih znanosti. Tu nam leži spas i opstanak.

\subsection{Uloga i kompetencije odgajatelja u odgojno-obrazovnoj misli Đoze i Gulena}

Opisujući značaj učitelja, Gulen ističe: Školu možemo posmatrati kao laboratoriju koja proizvodi eliksir koji može da spriječi ili da izliječi životne bolesti. Oni koji posjeduju znanje i mudrost da pripreme i primjene taj eliksir su-odgajatelji. ${ }^{25}$

Ovaj opis jasno naznačava prirodu obrazovnog sistema u djelima i mislima Đoze i Gullena. To je sistem zasnovan na principima vjere i nauke, teorije i prakse, ibadeta i društvene koristi. Škola kao takva mora da pripremi učenike za postizanje uspjeha, kako u ovom životu, tako i u onom budućem; Škola je mjesto učenja o svemu što je vezano za ovaj $\boldsymbol{i}$ budući svijet. ${ }^{26}$ Razmislimo o ovom opisu škole koji objedinjuje i vjerske i svjetovne nauke, radi konačne dobrobiti učenika. Iz ovog opisa dalje slijedi i logičan zaključak o važnosti odgajatelja u procesu edukacije: Istinski odgajatelji posiju čisto sjeme i njeguju ga. Oni se

\footnotetext{
24 Prljača Mustafa, Husein Đozo sabrana djela, tom I, str. 431.

25 http://www.fethullahgulen.org/about-fethullah-gulen/education/777-educationfrom-cradle-to-grave.html

26 Ibid.
} 


\section{zaokupiraju s onim što je dobro $i$ cjelovito; oni upućuju $i$ vode djecu u životu $i$ u svim događajima na koja mogu da naiđu. ${ }^{27}$}

Ukoliko usporedimo prethodno citirane osobine odgajatelja sa opisom koji nam nude J. Malić i V. Mužić, uvidjet ćemo da se istaknuto mjesto pridaje svijesti o vlastitoj društvenoj i ljudskoj ulozi koja se ogleda u pomoći u razvoju pojedinca: Da bi odgajatelj uspio, mora imati razvijen interes za odgajanika, poznavati njegove osobine, biti sposoban da ga shvati, da se u njega uřivi, tj. da ima sposobnost empatije, a te se njegove osobine moraju javljati i u odnosu prema drugim ljudima: roditeljima odgajanika, clanovima njegove radne organizacije, ali $i$ sire. ${ }^{28}$

Svi pedagozi ističu da se uloga učitelja zasniva na njegovim kompetencijama. S ovim u vezi postavlja se pitanje: Kakva se kompetentnost zahtijeva od nastavnika? Kako i u svim drugim zvanjima, ta se kompetentnost ne ograničava na stečena znanja i umijeća. Ona uključuje određena stajališta i ponašanja, koji su to važniji uzori za učenike - kako u budućnosti tako i u prošlosti, te su u društvu zajedno s roditeljima prvi prenositelji vrijednosti.

Da bi nastavnik mogao prihvatiti i funkcionisati s novim ulogama, mora, prije svega, biti dobar poznavatelj svoje struke, da solidno poznaje pedagogiju, psihologiju, didaktiku, metodike, filozofiju, da voli djecu i ima razvijene stvaralačke komunikacije i interpersonalne odnose, da je sposoban stvarati povoljnu pedagošku klimu u učeničkom i nastavničkom kolektivu, da je kreativan u radu i da oduševljava svojim radom. U svakodnevnom radu on rješava niz relevantnih pitanja, kao što su:

- problemi prilagođavanja učenika,

- racionalne i organizacione forme sticanja znanja, sposobnosti i navika,

- motivaciju učenika za cjelodnevnu odgojno-obrazovnu aktivnost (nastava u školi, samostalan rad kod kuće, organizirano provođenje slobodnog vremena),

- pomoć učenicima u regulisanju rada, odmora, igre i korisne zabave,

27 Ibid.

${ }^{28}$ Ramić Osman, Utjecaj karaktera učenika na školski uspjeh i ponašanje, Pedagoški fakultet u Bihaću, Bihać, 2011., str. 28. 
- biološki, medicinski i pedagoški rast i razvoj mlade ličnosti.

Prema Đozi i Gullenu, osnovni motiv za svakog ko se opredijeli za ovaj časni poziv morao bi biti zasnovan na bogobojaznosti i želji za ispunjenjem emaneta povjerenog svim odgajateljima. Svaki odgajatelj mora znati da je njegov zadatak, $u$ odnosu na sva ostala zanimanja, najbli ři radacima Allahovih poslanika, samim tim abiretska nagrada je i najveća za njih, odnosno kazna za pronevjere $i$ zapostavljanje emaneta najžešća. ${ }^{29}$

S obzirom da su poslanici bili najbolji i Bogu najbliži ljudi svog vremena, adekvatno tome imali su i najteža i najžešća iskušenja. Već smo ukazali na mnoštvo iskušenja koja u odmah u početku stoje pred svakim muallimom.

Posao odgajatelja podrazumijeva veliku ljubav prema djeci, želju da im pomogne da uče i uspiju u životu, a to će moći postići samo islamskim načinom življenja, uz želju da se slobodno razvijaju i sami spoznaju vrijednosti islama, spremnost da se permanentno usavršava $i$ obrazuje, predanost svojim zadacima i poslovima, entuzijazam, preciznost i odgovornost za kvalitetu svog rada: Riječ $\boldsymbol{i}$ djelo odgajatelja moraju ići paralelno, moraju se poklapati i međusobno potvrđivati. Dobar musliman mora sve svoje riječi, sve svoje tvrdnje i u djelima pokazati. Riječ bez djela, teorija bez prakse nema nikakve praktične vrijednosti. ${ }^{30}$

Kao što vidimo, a što i Husein Đozo kaže, svaki čovjek sebe predstavlja svojim postupcima. Lijepo ponašanje je odlika odgojenih i plemenitih ljudi. Takvi postupci čovjeku osiguravaju ugled u društvu, a veliku nagradu kod Allaha, dž. š. Ličnim primjerom pomoći drugom da popravi svoje postupke $\mathrm{i}$ učini dobro djelo u islamu je jedno od najvrijednijih djela. $U$ odlike jednog odgajatelja moramo svrstati i povjerenje, pouzdanost. Znamo da je Muhammed, a.s., u ranoj mladosti dobio nadimak El- Emin što znači povjerljiv, pouzdan. Pa zar ne bi trebao da bude takav jedan odgajatelj? Povjerenje se zadobiva lijepim postupkom, blagim i toplim riječima koje otvaraju ljudske duše. Moramo nastojati da druge ne prekidamo dok pričaju, da ib ne napadamo, ne vrijeđamo, ne ponižavamo. Moramo ih saslušati i pomoći im u njïhovom svijetu i stanju u kojem se nalaze. ${ }^{31}$

${ }^{29}$ Gullen Fethullah, Beskrajna svjetlost - Muhammed, a.s., El-Kalem, 2012., str. 44.

30 Prljača Mustafa, Husein Đozo sabrana djela, tom I, str. 166.

31 Ibid., str. 162. 
Zajednička osobina koja treba da krasi i učitelja i učenika jeste poniznost: Poniznost je znak da je corjek uistinu postao corjek. Od njenih znakova je $i$ to da se covjek ne promijeni nakon postizanja visokog položaja, bilo po vlasti, imetku, znanju, slavi, ili po bilo čemu što je javno. Ukoliko nakon ostvarivanja bilo koje od ovih stvari ljudi promijene svoje ideje, ponašanja ili karakter, ne mogu se smatrati kao da su postigli istinsku poniznost ili postali istinski ljudi.

\subsection{Ličnost odgajanika i odgojni proces u misli Đoze i Gulena}

Kako bi škola bila istinska obrazovna institucija, učenicima se mora prvo pružiti ideal; ljubav spram njihovog jezika i način da ga koriste na najefektniji način; lijep moral $i$ urođene ljudske vrijednosti. Niihov društveni identitet mora biti zasnovan na ovim temeljima. $^{32}$

U odgojno-obrazovnoj paradigmi Huseina Đoze i Fethullaha Gulena, postoje dvije bitne stvari koje se zahtijevaju od učenika, a one uključuju: poštovanje učitelja i nastavnog materijala (kao što su knjige, olovke itd.), i odnos spram nastavnog gradiva. Svrha poštovanja spram učitelja i nastavnog gradiva je prilično jasna i očigledna. Osnovni smisao je da učenik nema pravo niti smije da nanese zlo učitelju na bilo koji način, te da bi svoje materijale za učenje trebao organizirati i koristiti na ispravan način.

Uvažavanje nastavnika i materijala je, u skladu s tradicionalnim islamskim obrazovanjem, jednako važno kao i samo nastavno gradivo, ako ne $\mathrm{i}$ više $\mathrm{i}$ sve se to ubraja u islamsku etiku (moral): Lijep moral čine vrline $i$ on je visoko cijenjen, ma kod koga da se nađe. Oni s lijepim moralom su cijenjeni, mada bili i neobrazovani. Zajednice lišene kulture i obrazovanja su poput neotesanih pojedinaca, jer se $u$ njima ne nazire niti odanost $u$ prijateljstvu niti ustrajnost $u$ neprijateljstvu. ${ }^{33}$

Odgoj i obrazovanje nije proces koji teče samo s jedne strane strane učitelja. Neprihvatljivo je da se učitelj ophodi prema učeniku kao prema osobi koja samo treba da sluša i prihvata. Naprotiv, neophodan je

\footnotetext{
32 http://www.fethullahgulen.org/about-fethullah-gulen/education/777-educationfrom-cradle-to-grave.html

33 http://www.fethullahgulen.org/about-fethullah-gulen/education/773-upbringing.html
} 
kontakt i dijalog na relaciji učitelj - učenik, jer je odgoj i obrazovanje operacija koja je nezamisliva bez učestvovanja s obje strane.

Neki od nedostataka odgojno-obrazovne prakse našib škola ogledaju se u dominaciji uniformnog pristupa učenicima, nedostatku adekvatnog ambijenta, odsustvu interakcije i komunikacije na relaciji nastavnik - učenik - roditelj, prevladavanje predavackeog sistema rada, nedovoljna informiranost o napredovanju $i$ neredovnost u verifikaciji i ocjenjivanju znanja ǔenika. ${ }^{34}$ Škola u okviru pogleda islamske pedagogije nužno zahtijeva: sveobuhvatnost, interakciju na relaciji škola - porodica, kooperativne timove rada, mogućnost izbora pojedinih aktivnosti prema interesima, mogućnostima i sposobnostima učenika, funkcionalno ocjenjivanje i sistematski i individualizirani pristup učenicima.

S tim u vezi, osobito je bitno da odgajatelji u svojim svakodnevnim kontaktima s učenicima blagovremeno identifikuju traumatiziranu, asocijalnu, agresivnu i konfliktnu djecu te djecu koja su sklona pasivnom učešću u nastavnom procesu.

Konačni princip koji obuhvaća cijeli proces islamske edukacije je odnos poniznosti i etiketa usvajanja znanja koje su bitne od strane studenata i nastavnika. Tipičan primjer za to je da u tradicionalnom islamskom obrazovnom sistemu, studenti i nastavnici sjede na tlu. Samo kroz ovaj jedan primjer može se vidjeti poštovanje, poniznost i islamski bonton. Također, ovaj način podučavanja predstavlja i skrušenost i predanost Allahu, jer muslimani vjeruju da svo znanje dolazi od Allaha, Sveznajućeg. Usporedimo takav odnos između nastavnika i učenika sa savremenim školskim okruženjem gdje učenik sjedi na stolici. On ili ona će vjerojatno protezati noge van (najvjerovatnije prema nastavniku, a to se smatra znakom nepoštovanja). Gotovo uvijek, studenti će nasloniti leđa na stolice što uzrokuje pospanost (također se pospanost i zijevanje smatraju znakom nepoštovanja). Većinu vremena, učitelj mora stajati i dati predavanje, a studenti sjede udobno.

Postoje mnogi drugi aspekti islamske odgojno-obrazovne misli iz misli i djela islamskih velikana Huseina Đoze i Fethullaha Gulena, od kojih druge škole i institucije mogu imati koristi. Iako su ibadet i pokornost Allahu prvi i glavni prioritet u islamu, oni zahtijevaju i određeni nivo znanja. Stoga je znanje ugrađeno u samu bit islama, i ono je njegov ključ - temeljni aspekt.

${ }^{34}$ Ramić Osman, Utjecaj karaktera učenika na školski uspjeb i ponašanje, str. 27. 


\section{Zaključak}

Studija je dovela do slijedećih zaključaka:

- $\mathrm{U}$ istom vremenskom periodu, a na različitim geografskim podnebljima Gulen i Đozo su nastojali i to je najveća vrijednost njihovog cjelokupnog opusa i intelektualnoga pregnuća da u islamske studije ponovno uvedu ili reafirmiraju dinamično razumijevanje kur'anske ideje vremena $\mathrm{i}$ historije, na način na koji su to i najveći klasični autoriteti činili, stvarajući brilijantnu intelektualnu tradiciju sa kojom se muslimani uvrštavaju u red najciviliziranijih naroda u dosadašnjoj povijesti čovječanstva. Time je potvrđena početna hipoteza rada o mnogobrojnim korelacijskim vezama između misli i djela ova dva islamska učenjaka.

- Doprinos ove dvojice velikana na polju islamskog odgoja i obrazovanja je velik, samim tim što su kroz mnoštvo svojih tekstova pokušavali ljude i tadašnju ulemu da podstaknu na stjecanje znanja i rad po njemu, podsjećali na opasnosti zanemarivanja nauke i budili uspavane islamske mislioce.

- Čitajući njihove radove nailazimo na brojne probleme koje su imali muslimani njihovog i današnjeg vremena, bez obzira da li se to ogledalo kroz internost uleme, u neadekvatnoj obrazovnoj politici, slabom vjerskom obrazovanju muslimana i mnogi drugi problemi. Danas su ti problemi uveliko prisutni kod nas, tako da se mogu izvući velike pouke iz misli i djela ovih dvaju reformatora kako bismo krenuli njihovim stopama te probudili uspavane muslimane, a što je cilj svakog onoga koji je angažiran na polju islamske pedagogije;

- Ideja koja se može razabrati kao manje-više prisutna u cjelokupnom Đozinom i Gulenovom misaonom nastojanju je misao islamske obnove ili oživljavanja islamskog učenja u muslimanskom izvornom razumijevanju i integralnoj primjeni kur'anskih principa, koncepcija i poruka, kao savremena originalna islamska odgojnoobrazovna paradigma. U njihovim tekstovima pokazuje se stalno isti cilj: pokretanje današnjih muslimana da budu svjesniji i utoliko istinitiji muslimani, da u učenju islama nalaze poticaje, izvorište i osnovu za svestrano razvijanje vlastitih kreativnih snaga i život duha kao što su to bili muslimani klasičnog razdoblja. Ovi velikani islamske misli zajednički dijele nepokolebljivo uvjerenje u to da islam pruža neprolazne poticaje $i$ mogućnosti za nova misaona i djelatna potvrđivanja muslimana u svim višim oblicima ljudskog opstanka. Štaviše, da je islamski inspirirana 
praksa vrhunac cjelovitog, slobodnog i odgovornog življenja čovjeka kao Božijeg namjesnika na Zemlji;

- Čovjekova egzistencija je za Đozu i Gulena jedinstvo etičke i društvene egzistencije: etičke u smislu čovjekova moralnog angažmana i intimne borbe sa slabostima u sebi, i društvene u smislu društvene angažiranosti i borbe sa izazovima i problemima u svijetu. Stoga je i prioritet njihove misli društveni aktivizam i objedinjavanje teorije $\mathrm{i}$ prakse. Ključne riječi u njihovom vokabularu su vjera, misao i djelo, ali sa naglašenim dinamiziranjem kao vjerovanje, mišljenje i djelovanje.

\section{Literatura:}

1. Korkut, Besim: Prijevod Kur'ana, Medina, 1412. h. g.

2. Abdulkadir Muhammed Salih: Tefsir i mufessiri u savremenom dobu, FIN i El-Kalem, Sarajevo, 2008.

3. Adilović, Ahmed: Velikani tefsirskih znanosti, Elči Ibrahim-pašina medresa u Travniku, Travnik, 2003.

4. Gullen, Fethullah: Svjetlosti na putu Istine, El-Kalem, Sarajevo, 2011.

5. Gullen, Fethullah: Beskrajna svjetlost-Muhammed, a.s., El-Kalem, Sarajevo, 2011.

6. Kutb, Sejjid: U okrilju Kur'ana, FIN, Sarajevo, 1998.

7. Muftić, Teufik: Arapsko-bosanski rječnik, El-Kalem, Sarajevo, 2004.

8. Prljača, Mustafa: Husein Đozo - Sabrana djela - Knjiga prva, El-Kalem, Sarajevo, 2006.

9. Ramić, Osman: Utjecaj karaktera ǔcenika na školski uspjeh i ponašanje, Pedagoški fakultet u Bihaću, Bihać, 2011.

10. Šeltut, Mahmud: Komentar Kur'an-i-kerima (prvih deset ď̌uz̧eva), FIN i El-Kalem, Sarajevo, 2008.

11. Terzić, Izet: Mudrost istoka, IPF u Bihaću, Bihać, 2007.

12. Ünal, Ali and Alphonse Williams, eds. Advocate of Dialogue: Fethullah Gülen. Fairfax, VA: The Fountain

13. Wan Mohd Nor Wan Daud, Syed Mubammad Naquib Al-Attas - obrazovna filozofija i praksa, Tugra, Sarajevo, 2010.

14. Zbornik radova: Fakultet islamskih nauka u Sarajevu, br. XI. Sarajevo, 2006.

15. Zbornik radova sa naučnog simpozija: Život $i$ djelo Husein ef. Đoze, FIN, Sarajevo, 1998. 


\section{Internet-stranice:}

16. www.fethullahgulen.org

17. en.wikipedia.org 
Nedim Botic, BA

\title{
EDUCATIONAL THOUGHT OF HUSSEIN DJOZO AND FETHULLAH GULEN
}

\begin{abstract}
This work which is based upon analysis of educational thought of Fethullah Gulen and Hussein Djozo tries to assess possible correlations between the teachings of these two scholars. Starting bypothesis is that their educational thought contains a large number of similar elements. Because a similar paper has not yet been written, this article has a great importance for the pedagogical science in general, and especially Islamic pedagogy. The work is composed of several chapters, which discuss common aspects of educational thought and Djozo and Gulen. They include: the concept and importance of education, social activism and the importance of uniting theory and practice, the relationship between religious and secular knowledge, personality of students and educators, and the nature of the educational process. Methods which have been used are: analytical method (content analysis, functional analysis, comparative analysis), deductive methods, methods of synthesis and abstraction. Work came to a conclusion that both Gulen and Djozo tried to reintroduce in Islamic Studies or reaffirm a dynamic understanding of the Qur'anic idea of time and history, in the manner of the most classic authorities, creating a brilliant intellectual tradition with which Muslims are listed in order of the most civilized nations in the human history. This confirmed the initial hypothesis of multiple correlations between the thoughts and actions of these two Islamic scholars, and as a contribution to Islamic pedagogical thought.
\end{abstract}

Keywords: Gulen, Djozo, educational thoughts, correlation, Islamic pedagogy 


\section{الأستاذ نديم بوتيتش}

\section{الفكر التربوي التعليمي لدى حسين جوزو وفتح الله غولن}

\section{الخلاصية}

يحاول هذا البحث العلمي، من خلال تحليل الفكر التربوي التعليمي لدى فتح الله غولن وحسين جوزو، إثبات احتمال وجود علاقات الارتباط بين فكر هذيْن العالمينّ. الفرضية الأولية تقول إن فكرهما التربوي التعليمي يحتوي على مواد مشتركة. علماً بأنها

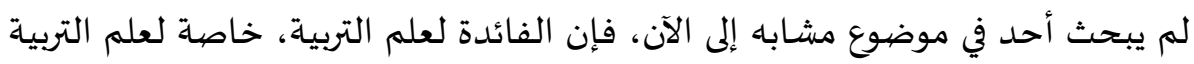

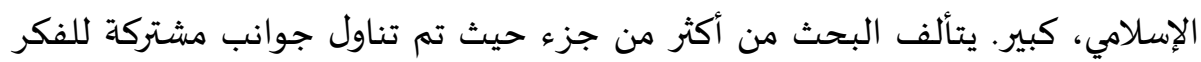

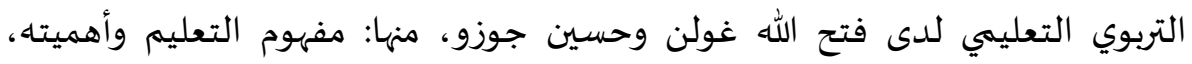

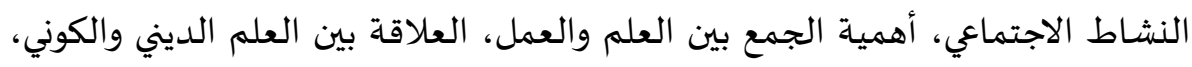

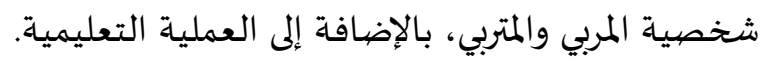
الطرق المستخدمة في البحث هي: الطريقة التحليلية (تحليل المحتوى، التحليل الفعال، التحليل المقارن)، طريقة الاستنتاج، التركيب وطريقة التجرد.

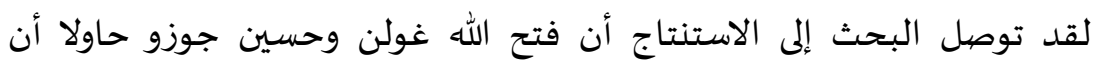

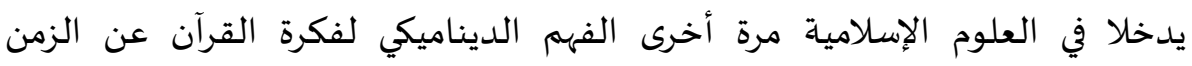

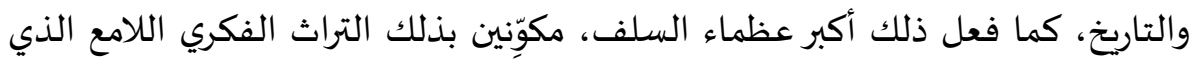

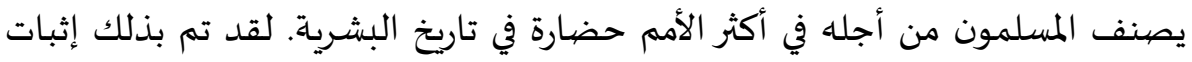

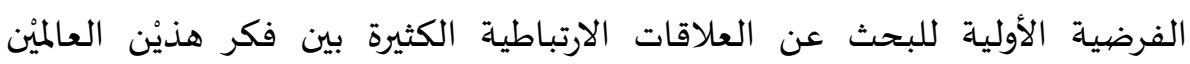

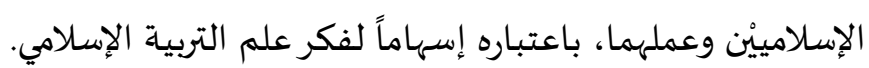

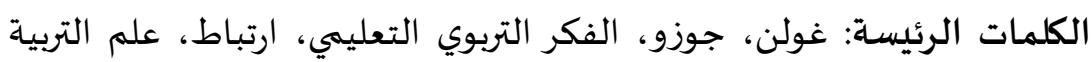

الإسبلامي 